\title{
A single column separation method for barium isotope analysis of geologic and hydrologic materials with complex matrices
}

\author{
R. M. Matecha', R. C. Capo ${ }^{1}$, B. W. Stewart ${ }^{1 *}\left(\mathbb{D}\right.$, R. L. Thompson ${ }^{2,3}$ and J. A. Hakala²
}

\begin{abstract}
The increasing significance of barium (Ba) in environmental and geologic research in recent years has led to interest in the application of the Ba isotopic composition as a tracer for natural materials with complex matrices. Most $\mathrm{Ba}$ isotope measurement techniques require separation of $\mathrm{Ba}$ from the rest of sample prior to analysis. This paper presents a method using readily available materials and disposable columns that effectively separates Ba from a range of geologic and hydrologic materials, including carbonate minerals, silicate rocks, barite, river water, and fluids with high total dissolved solids and organic content such as oil and gas brines, rapidly and without need for an additional cleanup column. The technique involves off-the-shelf columns and cation exchange resin and a two-reagent elution that uses $2.5 \mathrm{~N} \mathrm{HCl}$ followed by addition of $2.0 \mathrm{~N} \mathrm{HNO}_{3}$. We present data to show that major matrix elements from almost any natural material are separated from Ba in a single column pass, and that the method also effectively reduces or eliminates isobaric interferences from lanthanum and cerium.
\end{abstract}

Keywords: Barium, Ba isotopes, Barite, MC-ICPMS, Column chromatography

\section{Introduction}

Barium $(\mathrm{Ba})$ is a critical element of interest in studies of oceanic biogeochemical cycling and the diagenetic alteration of sediments (e.g., [1-5]), and the isotopic composition of $\mathrm{Ba}$ has been used to understand element cycling in marine, riverine, lacustrine and pedogenic environments [6-16]. More recently, Ba concentrations [17-19] and its isotope signatures [20] have been studied as indicators of Ba sources and mobility related to subsurface water-rock interactions and the fate and transport of contaminants in drilling mud, solid waste and produced waters related to hydraulic fracturing of oil and gas wells.

In order to obtain the Ba isotope composition of a sample via thermal ionization mass spectrometry (TIMS) or

\footnotetext{
*Correspondence: bstewart@pitt.edu

${ }^{1}$ Department of Geology \& Environmental Science, University of Pittsburgh, Pittsburgh, PA 15260, USA
}

Full list of author information is available at the end of the article multi-collector inductively coupled plasma mass spectrometry (MC-ICPMS), the Ba must be separated from other elements in the sample. High levels of matrix elements will interfere with the ionization and transmission of $\mathrm{Ba}$, and elements with directly overlapping isotopic masses (isobaric interferences, including Xe, La, and Ce) change the measured $\mathrm{Ba}$ isotope ratios unless they are removed prior to and/or corrected for during isotope ratio measurement [21-27]. While Xe is only introduced during MC-ICPMS measurement from the atmosphere and Ar gas source, all other interferents (matrix major elements, $\mathrm{La}$, and $\mathrm{Ce}$ ) must be removed via chemical processing prior to analysis by TIMS or MC-ICPMS. For samples with high ratios of Ba to matrix and/or isobaric interferents (e.g., high-Ba formation waters or samples of barite, $\mathrm{BaSO}_{4}$ ), the chemical separation of $\mathrm{Ba}$ is relatively straightforward $[6,14,20,24,28,29]$. However, silicate rock samples can have high rare earth element (REE) to original author(s) and the source, provide a link to the Creative Commons licence, and indicate if changes were made. The images or other third party material in this article are included in the article's Creative Commons licence, unless indicated otherwise in a credit line to the material. If material is not included in the article's Creative Commons licence and your intended use is not permitted by statutory regulation or exceeds the permitted use, you will need to obtain permission directly from the copyright holder. To view a copy of this licence, visit http://creativecommons.org/licenses/by/4.0/. The Creative Commons Public Domain Dedication waiver (http://creativeco mmons.org/publicdomain/zero/1.0/) applies to the data made available in this article, unless otherwise stated in a credit line to the data. 
$\mathrm{Ba}$ ratios, necessitating robust procedures for removing $\mathrm{La}$ and Ce prior to analysis.

Various methods for the separation of Ba for isotopic analysis have been reported in detail. Miyazaki et al. [30] described an elution method using $2.5 \mathrm{~N}$ hydrochloric acid $(\mathrm{HCl})$ to separate matrix major elements followed by $1.5 \mathrm{~N}$ nitric acid $\left(\mathrm{HNO}_{3}\right)$ to enhance separation of $\mathrm{Ba}$ from REE in silicate rock samples. However, two major isotopes of $\mathrm{Ba}\left({ }^{136} \mathrm{Ba}\right.$ and $\left.{ }^{138} \mathrm{Ba}\right)$ were excluded from the MC-ICPMS measurement protocol due to interferences from ${ }^{138} \mathrm{La},{ }^{136} \mathrm{Ce}$, and ${ }^{138} \mathrm{Ce}[30]$. Nan et al. [23] used a similar elution method $(3.0 \mathrm{~N} \mathrm{HCl}$ followed by $4.0 \mathrm{~N} \mathrm{HNO}_{3}$ ), using two successive columns to fully remove interferents. Elution curves for $\mathrm{La}$ and $\mathrm{Ce}$ were not reported in this study. For separation of Ba from a range of silicate and carbonate rock types, Nan et al. [31] and Zeng et al. [25] reported using up to three column passes to fully separate Ba from the REE. Tian et al. [28] described a method for separation of Ba from barite using $3 \mathrm{~N} \mathrm{HCl}$ and $3 \mathrm{~N} \mathrm{HNO}_{3}$. Because barite consists of $\sim 59 \%$ Ba by weight, matrix and isobaric interferences are negligible, and the Ba could be purified in a single step.

This paper describes sample preparation and ion exchange chromatography separation of Ba using a tworeagent elution in a single off-the-shelf column that is suitable for the isotopic analysis of $\mathrm{Ba}$ in samples with complex matrices and a range of $\mathrm{REE} / \mathrm{Ba}$ ratios that are encountered in geologic and environmental samples. In addition to barite and seawater, we demonstrate that the method is applicable to low-Ba silicates and carbonate rocks, river water, and high total dissolved solid (TDS) fluids containing organic compounds, such as oil and gas produced waters and other brines. The method uses readily available polypropylene disposable columns and cation exchange resin. We document that this method successfully separates Ba from matrix major elements, as well as $\mathrm{La}$ and $\mathrm{Ce}$, in one step, thus necessitating minor to negligible correction for these isobaric interferences during measurement by MC-ICPMS.

\section{Experimental methods}

\section{Materials and reagents}

Experimental work was conducted at the University of Pittsburgh under clean lab conditions. Ultrapure 18.2 $\mathrm{M} \Omega$ Milli-Q water (MQW) was used for acid dilutions and for washing solids. Teflon beakers and other sample vessels were acid washed, and most sensitive procedures (e.g., sample dissolution, spiking, evaporation, and column separations) were carried out in ULPA-filtered laminar flow hoods. Cation exchange resin (Bio-Rad $A{ }^{\circledR}$ 50W-X8 200-400 mesh) was pre-cleaned with repeated, sequential applications of $\mathrm{MQW}, 2 \% \mathrm{HNO}_{3}$, and $6 \mathrm{~N} \mathrm{HCl}$, which were added to the resin in a fluorinated ethylene propylene (FEP) bottle, shaken vigorously, and decanted after settling. Ultrapure (Fisher Optima ${ }^{\mathrm{TM}}$ ) $\mathrm{HCl}, \mathrm{HNO}_{3}$, hydrofluoric acid (HF) and hydrogen peroxide $\left(\mathrm{H}_{2} \mathrm{O}_{2}\right)$ were used for sample dissolution and preparation, resin/ column preparation, elution and organic matter removal. Ultrapure (J.T. Baker ${ }^{\mathrm{TM}}$ Ultrex $^{\mathrm{TM}}$ ) sodium carbonate $\left(\mathrm{Na}_{2} \mathrm{CO}_{3}\right)$ was used for barite dissolution and seawater Ba precipitation. The $\mathrm{Na}_{2} \mathrm{CO}_{3}$ solution was further purified to remove $\mathrm{Ba}$ by using a modification of the method described by Foster et al. [32]; in this method, $1.15 \mathrm{M}$ $\mathrm{Na}_{2} \mathrm{CO}_{3}$ solution is reacted with a $1.1 \mathrm{~N}$ calcium chloride solution $\left(\mathrm{CaCl}_{2}\right.$; Thermo Fisher Alfa Aesar ${ }^{\mathrm{TM}}$ 99.99\% purity), which precipitates $\mathrm{Ba}$ along with calcium carbonate, and results in an approximately $1 \mathrm{M} \mathrm{Na}_{2} \mathrm{CO}_{3}$ solution with low Ba levels.

To prevent sample carryover, we used disposable polypropylene gravity flow ion exchange columns (Bio-Rad Poly-Prep ${ }^{\circledR}$ Chromatography Columns) and disposed of the column and the resin after each use. The columns have a $2 \mathrm{~mL}$ bed volume with a $10 \mathrm{~mL}$ reservoir and a porous $30 \mu \mathrm{m}$ polyethylene bed support frit (Fig. 1).

\section{Samples for Ba separation experiments}

Verification of method applicability was conducted using natural materials and standards which reflect a range of matrices encountered in geologic and environmental samples. Silicate rocks (shale, sandstones, igneous rocks) can be problematic for $\mathrm{Ba}$ isotopic analysis because of potentially high levels of REE interferents relative to $\mathrm{Ba}$. Carbonate minerals such as limestone and marine shells have high $\mathrm{Mg}$ and $\mathrm{Ca}$ content, and some freshwater aragonite shells can have high REE relative to $\mathrm{Ba}$ [33]. Oil and gas produced waters have high TDS, can contain hydrocarbons and other organic compounds, and can vary greatly in Ba content $(0.25$ to $>10,000 \mathrm{ppm}[34,35])$. For the experiments reported here, fluid samples included seawater (National Research Council Canada seawater reference material NASS- 6 collected off the coast of Nova Scotia, Canada), surface water from the Ohio River in Pennsylvania, USA (OR-1204-1a), and produced water from the Marcellus Formation in Greene County, Pennsylvania (M4TFA0518; also used as an internal lab $\mathrm{Ba}$ isotope standard). The carbonate sample (PA-LO102714) was a freshwater mussel shell collected in western Pennsylvania. Silicate rock samples include volcanics from southern Alaska [36], an organic-rich black shale (Marcellus Shale), and USGS standards BCR-2 basalt and AGV-1 andesite [37]. Selected data for these samples are provided in Additional file 1: Table S1.

\section{Sample dissolution/Ba concentration methods}

The carbonate mussel shell was powdered and dissolved in $2.5 \mathrm{~N} \mathrm{HCl}$. The silicate rock samples were dissolved 

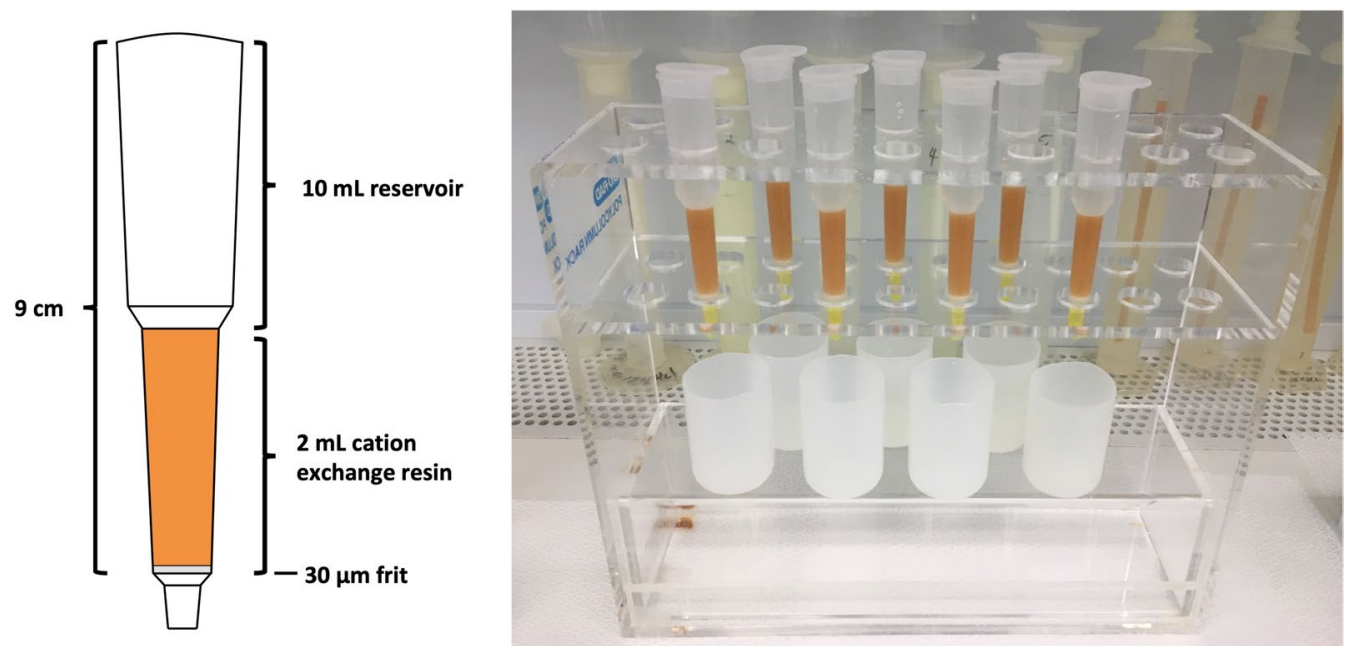

Fig. 1 Bio-Rad Poly-Prep ${ }^{\circledR}$ Chromatography Columns used in Ba separation experiments

under clean lab conditions using $\mathrm{HF}$ and $\mathrm{HNO}_{3}$ in a microwave digestion system (Milestone Ethos ${ }^{\circledR}$ ). Following digestion at $200{ }^{\circ} \mathrm{C}$, the samples were treated with aqua regia and concentrated $\mathrm{HNO}_{3}$ to remove fluorides.

Barite was dissolved following a method based on earlier work [14, 28, 38, 39]. In brief, powdered barite was reacted with $1 \mathrm{M}$ purified $\mathrm{Na}_{2} \mathrm{CO}_{3}$ solution $(1 \mathrm{~mL} / 10 \mathrm{mg}$ barite) at $95{ }^{\circ} \mathrm{C}$ in a sealed Savillex ${ }^{\circledR}$ vial, leading to exchange of $\mathrm{SO}_{4}{ }^{2-}$ with $\mathrm{CO}_{3}{ }^{2-}$. After centrifuging, the supernatant was discarded, and the reaction was repeated twice on the remaining residue for a total of $72 \mathrm{~h}$, resulting in a precipitate of barium carbonate $\left(\mathrm{BaCO}_{3}\right)$. The precipitate was rinsed with $\mathrm{MQW}$, evaporated to dryness, and the carbonate dissolved in $3 \mathrm{~N} \mathrm{HNO}_{3}$. The sample was dried down, redissolved, and diluted to $2 \% \mathrm{HNO}_{3}$ for elemental analysis.

Because $\mathrm{Ba}$ is present at low concentrations (30$175 \mathrm{nM})$ in seawater $[1-3,7,9-11]$, it must be concentrated prior to column separation in order to reduce the matrix load. Barium was extracted from seawater (NASS-6) using a method modified from Foster et al. [32] and others [7, 10-12]. An aliquot of seawater containing $\sim 2 \mu \mathrm{g} \mathrm{Ba}(\sim 200 \mathrm{~mL})$ was spiked with a ${ }^{137} \mathrm{Ba}-{ }^{135} \mathrm{Ba}$ solution (see next section) so that isotope mass fractionation associated with all subsequent processing could be corrected for during measurement. The aliquot was reacted with sufficient $1 \mathrm{M} \mathrm{Na}_{2} \mathrm{CO}_{3}$ solution (purified to remove $\mathrm{Ba}$ ) to result in precipitation of calcium carbonate, which scavenges $\mathrm{Ba}$ from solution. This occurs at a molar ratio of $\mathrm{CO}_{3}{ }^{2-}$ to $\mathrm{Ca}^{2+}$ of approximately 6:1. Once saturation was reached, the reaction occurred nearly instantaneously, and the crystal-fluid mixture was then stirred for $5 \mathrm{~min}$ to ensure full removal of $\mathrm{Ba}$. The sample was then decanted into $50 \mathrm{~mL}$ centrifuge tubes, rinsing any residue into the tubes using MQW, and centrifuged at $4000 \mathrm{rpm}$ for $5 \mathrm{~min}$. The supernatant was removed by pipette, preserving the precipitate (with most of the $\mathrm{Ba}$ ) in the centrifuge tube. The precipitate was transferred to a Savillex vial using MQW and a vortex mixer as needed and evaporated to near dryness at $90^{\circ} \mathrm{C}$. The carbonate precipitate was then dissolved in $4 \mathrm{~N} \mathrm{HCl}$, evaporated to dryness, and redissolved in $0.5 \mathrm{~mL} 2.5 \mathrm{~N} \mathrm{HCl}$ for cation column separation. This method can also be used for separation of $\mathrm{Ba}$ from other high TDS fluids and brines with a low $\mathrm{Ba}$ concentration and sufficient $\mathrm{Ca}$ for precipitation.

\section{Barium double spike}

A calibrated double $\mathrm{Ba}$ isotope spike was added to dissolved samples prior to loading of the columns and was used to correct for mass fractionation during MCICPMS analysis. Previous work [6-9, 23, 24, 30, 40-43] has shown that this can correct for mass fractionation during chemical processing, thus obviating the need for full (>99\%) recovery of Ba from the column. In addition, use of a double spike reduces the effects of non-isobaric matrix interferents [24]. Based on error analysis using the double spike tool of Rudge et al. [44], the ${ }^{137} \mathrm{Ba}-{ }^{135} \mathrm{Ba}$ isotope pair was chosen because it optimizes the precise determination of ${ }^{138} \mathrm{Ba} /{ }^{134} \mathrm{Ba}$, whether obtained by direct measurement or calculated based on the measured fractionation in the ${ }^{138} \mathrm{Ba} /{ }^{136} \mathrm{Ba}$ ratio. The double spike was made using ${ }^{135} \mathrm{Ba}$ - and ${ }^{137} \mathrm{Ba}$-enriched carbonate salts from the National Isotope Development Center at Oak Ridge National Laboratory and calibrated by running mixtures of double spike and NIST 3104a. Further details 
of spike calibration can be found in the Supporting Information of Tieman et al. [20].

\section{Cation column separation procedure}

For some samples with very low REE/Ba (carbonate shell PA-LO-102714 and produced water M4TFA0518), a mixed REE standard was added prior to column experiments in order to test the separation of Ba more rigorously from the isobaric interferents $\mathrm{La}$ and $\mathrm{Ce}$. In the experiments reported here, approximately $3 \mathrm{~mL}$ of cleaned AG50W 200-400 mesh cation resin suspended in MQW was incrementally added by pipette to the acid cleaned columns until the resin bed was just above the base of the $10 \mathrm{~mL}$ column reservoir. The resin bed was acidified with $3 \mathrm{~mL}$ of $\mathrm{HCl}$ at the normality used for that elution experiment, and the resin adjusted to ensure no air bubbles were left and that the top of the resin bed was aligned with the base of the column reservoir. The resinfilled columns were then cleaned with $5 \mathrm{~mL}$ of $6.0 \mathrm{~N} \mathrm{HCl}$ and equilibrated with $4.5 \mathrm{~mL}$ of $\mathrm{HCl}$ at the appropriate elution normality, added incrementally.

Prior to loading the sample into the columns, residual organics were removed from the sample by adding $1 \mathrm{~mL}$ of $50 \% \mathrm{H}_{2} \mathrm{O}_{2}$ drop wise, followed by evaporation to dryness. The sample was then redissolved in $0.5 \mathrm{~mL}$ of $\mathrm{HCl}$ at the appropriate elution normality, allowed to equilibrate for a minimum of $2 \mathrm{~h}$, and placed in an ultrasonic bath for $30 \mathrm{~min}$ to ensure that it was dissolved to the fullest extent possible. Samples were centrifuged in $2 \mathrm{~mL}$ polypropylene centrifuge tubes at $4000 \mathrm{rpm}$ for $10 \mathrm{~min}$ to prevent any insoluble precipitates from being loaded onto the cation exchange resin bed. The supernatant was added to the prepared column using a pipette with a $1 \mathrm{~mL}$ polypropylene tip. The sample matrix (excluding $\mathrm{Ba}$ and the REE) was eluted by adding $\mathrm{HCl}$ of the appropriate normality in successive increments, and the eluent was collected for elemental analysis. This was followed by the addition of either $\mathrm{HCl}$ or $\mathrm{HNO}_{3}$, depending on the experiment, and these samples (containing primarily $\mathrm{Ba}$ and the REE) were collected for elemental analysis.

\section{Analysis of column calibration cuts}

Elemental chemistry of column calibration cuts was determined on a Thermo Element $\mathrm{XR}^{\circledR}$ sector field (SF) ICP-MS at the at the National Energy Technology Laboratory (NETL). The SF-ICP-MS sample introduction system used a Glass Expansion Ezylok Micromist nebulizer and Twister spray chamber. The SF-ICP-MS gas flow rates and mass spectrometer voltages were optimized daily in low resolution mode to obtain the maximum signal intensity while minimizing doubly charged and oxide species. Barium, $\mathrm{Sr}$, and REE were analyzed using the low resolution slit $(\Delta \mathrm{m} / \mathrm{m}=300)$, while second row non-metals and Fe were analyzed using the medium resolution slit $(\Delta \mathrm{m} / \mathrm{m}=4000)$.

All samples were spiked with $10 \mu \mathrm{g} / \mathrm{L}$ indium as an internal standard prior to analysis to account for matrix differences. Samples which contained high TDS were minimally diluted with $2 \% \mathrm{HNO}_{3}$ prior to analysis to minimize matrix effects affecting the ionization in the plasma. While quantitation was not required to generate the elution curves, limits of detection (LOD) were calculated for all analytes as 3 times the standard deviation of the blank from three consecutive blank runs. These detection limits are listed in Table 1. Data from these experiments are reported in Additional file 1: Tables S2-S5.

\section{Ba isotope mass spectrometry method}

A subset of samples was analyzed for Ba isotopic composition on a Thermo Neptune Plus ${ }^{\circledR}$ MC-ICPMS at the University of Pittsburgh, part of a joint NETL-University of Pittsburgh facility. For these samples, the separated $\mathrm{Ba}$ cut was evaporated to dryness at $90{ }^{\circ} \mathrm{C}$, dissolved in $1 \mathrm{~mL}$ of concentrated $\mathrm{HNO}_{3}$, and sonicated for 10 min before again being evaporated to dryness. The sample was redissolved in $2 \% \mathrm{HNO}_{3}(2 \mathrm{~mL}$ per $\mu \mathrm{g}$ of $\mathrm{Ba})$, sonicated in the sealed container for $60 \mathrm{~min}$, and transferred to an acid cleaned $15 \mathrm{~mL}$ centrifuge tube for MC-ICPMS analysis.

We report the isotope ratio of $\mathrm{Ba}$ as $\delta^{138} \mathrm{Ba}$, which is the permil deviation of the ${ }^{138} \mathrm{Ba} /{ }^{134} \mathrm{Ba}$ ratio of a sample from that of NIST Standard Reference Material 3104a:

$$
\delta^{138} B a=10^{3}\left[\frac{\left({ }^{138} B a /{ }^{134} B a\right)_{\text {sample }}}{\left({ }^{138} B a /{ }^{134} B a\right)_{3104 a}}-1\right]
$$

Samples were introduced into the MC-ICPMS using an ESI Apex ${ }^{\circledR}$ desolvating nebulizer. Barium isotopes $\left({ }^{134} \mathrm{Ba}\right.$, ${ }^{135} \mathrm{Ba},{ }^{136} \mathrm{Ba},{ }^{137} \mathrm{Ba},{ }^{138} \mathrm{Ba}$ ) were measured simultaneously on five Faraday cups using $10^{11} \Omega$ resistors. Isobaric interferences from $\mathrm{Xe}, \mathrm{La}$ and $\mathrm{Ce}$ were monitored by measurement of ${ }^{131} \mathrm{Xe},{ }^{139} \mathrm{La}$ and ${ }^{140} \mathrm{Ce}$ on three additional Faraday cups. Xenon, which is present in the atmosphere and can have variable concentrations in the argon gas used in MC-ICP-MS analysis, has interfering masses at

Table 1 Limits of detection (LOD) for all isotopes monitored in this work by SF-ICP-MS

\begin{tabular}{|c|c|c|c|}
\hline \multicolumn{2}{|c|}{ Medium resolution } & \multicolumn{2}{|c|}{ Low resolution } \\
\hline Isotope & LOD, $\mu \mathrm{g} / \mathrm{L}$ & Isotope & LOD, $\mu \mathrm{g} / \mathrm{L}$ \\
\hline${ }^{23} \mathrm{Na}$ & 0.487 & ${ }^{88} \mathrm{Sr}$ & 0.0004 \\
\hline${ }^{24} \mathrm{Mg}$ & 0.341 & ${ }^{137} \mathrm{Ba}$ & 0.0069 \\
\hline${ }^{44} \mathrm{Ca}$ & 0.434 & ${ }^{139} \mathrm{La}$ & 0.0001 \\
\hline${ }^{56} \mathrm{Fe}$ & 0.0086 & ${ }^{140} \mathrm{Ce}$ & 0.0002 \\
\hline
\end{tabular}


134 and 136 (10.44\% and $8.87 \%$ of total $\mathrm{Xe})$. Cerium is an isobaric interferent of $\mathrm{Ba}$ at mass $136\left({ }^{136} \mathrm{Ce}=0.185 \%\right.$ of total $\mathrm{Ce}$ ), and both $\mathrm{Ce}$ and $\mathrm{La}$ are isobaric interferents at mass $138\left({ }^{138} \mathrm{Ce}=0.251 \%\right.$ of total $\mathrm{Ce}$ and ${ }^{138} \mathrm{La}=0.09 \%$ of total La). Typical ${ }^{138} \mathrm{Ba}$ intensities were $30-40 \mathrm{~V}$ for the Apex ${ }^{\circledR}$ desolvating nebulizer $(\sim 200 \mathrm{~V} / \mathrm{ppm} \mathrm{Ba})$. No apparent systematic variation in $\delta^{138} \mathrm{Ba}$ was observed within this range of signal intensity. Mass fractionation of the sample was corrected for by iterative normalization to the ${ }^{137} \mathrm{Ba} /{ }^{135} \mathrm{Ba}$ of the double spike using an exponential law [45]. The detector configuration and additional details of the mass spectrometric methods can be found in Supporting Information in Tieman et al. [20].

\section{Results and discussion}

\section{Optimal separation of $\mathrm{Ba}$}

Combinations of different normalities of $\mathrm{HCl}(1.5-2.5 \mathrm{~N})$ and $\mathrm{HNO}_{3}(1-3 \mathrm{~N})$ were tested to optimize the purity of the Ba cut while minimizing the volume and concentration of reagent necessary to elute. Results of selected experiments are reported in Additional file 1: Tables S2S5; Figures S1, S2. Use of $2.5 \mathrm{~N} \mathrm{HCl}$ up to the beginning of Ba elution resulted in the optimal separation of major matrix elements from Ba (Fig. 2). Experiments in which only $\mathrm{HCl}$ was used for elution (including of $\mathrm{Ba}$ ) resulted in either overly large volumes of acid being required to fully capture the $\mathrm{Ba}$ (e.g., $2.0 \mathrm{~N} \mathrm{HCl}$; Additional file 1: Figure S1a) or significant overlap of Ba with the isobaric interferents $\mathrm{La}$ and $\mathrm{Ce}$ (e.g., $2.5 \mathrm{~N} \mathrm{HCl}$; Additional file 1: Figure S1b). van Zuilen et al. [24] report using $2.0 \mathrm{~N}$ or 6.4 $\mathrm{N} \mathrm{HCl}$ to elute $\mathrm{Ba}$, but do not report elution curves for La or Ce. The absence of these peaks during the TIMS measurement [24] may reflect the lower ionization efficiency of these elements relative to Ba rather than separation from the Ba cut. Previous work demonstrated that

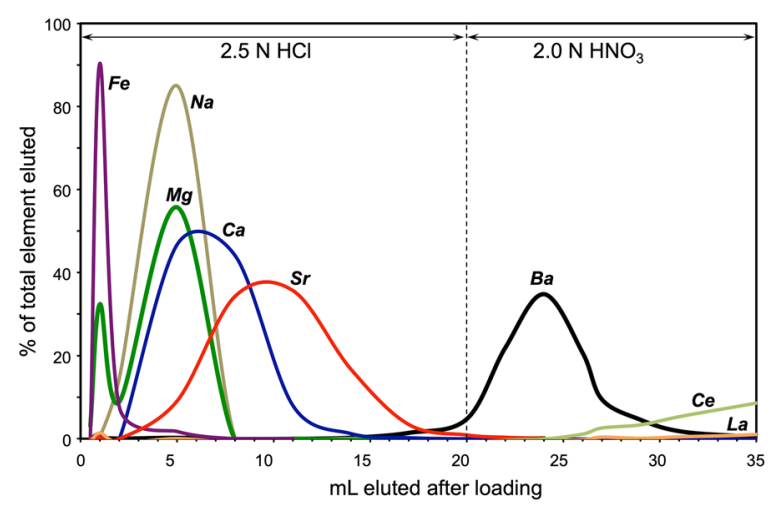

Fig. 2 Column matrix separation for major elements and Ba for a $60 \mathrm{mg} \mathrm{CaCO}$ (freshwater mussel shell) sample. Cerium and La were not fully recovered even after $60 \mathrm{~mL}$, so their \% elution values are likely overestimated a better separation of $\mathrm{Ba}$ from the REE could be achieved by eluting with $\mathrm{HNO}_{3}[23,28,30]$; therefore, we tested different normalities of $\mathrm{HNO}_{3}$ for optimal elution of $\mathrm{Ba}$ while minimizing overlap of $\mathrm{La}$ and $\mathrm{Ce}$. Use of higher normality acid results in a tighter Ba elution peak but greater overlap of REE with Ba (e.g., Additional file 1: Figure S2a,b). The optimal concentration of $\mathrm{HNO}_{3}$ to elute $\mathrm{Ba}$ from the columns used in these experiments was $2.0 \mathrm{~N}$ (Fig. 2).

The separation of Ba from REE isobaric interferents was further tested by analyzing Ba elution curves in detail using a dissolved volcanic rock with $\mathrm{La} / \mathrm{Ba}$ of $\sim 0.015$ and $\mathrm{Ce} / \mathrm{Ba}$ of $\sim 0.033$, and a Marcellus Shale produced water sample in which $\mathrm{La}$ and Ce were added to increase $\mathrm{La} / \mathrm{Ba}$ and $\mathrm{Ce} / \mathrm{Ba}$ to $\sim 0.67$ (Fig. 3). Based solely on the measured signal intensities (reported in counts per second) by SFICP-MS and the abundance of the measured isotope, the overlap of La with the Ba cut is $0.007 \%$ for the volcanic sample and $0.1 \%$ for the La-enriched produced water sample. Similarly, the overlap of Ce with the $\mathrm{Ba}$ cut is $0.03 \%$ and $1.1 \%$ for the volcanic sample and Ce-enriched produced water, respectively. In the latter case, such an overlap in Ce would necessitate a correction of $\sim 0.3 \%$ to the $\delta^{138} \mathrm{Ba}$ (for the measurement method described here),

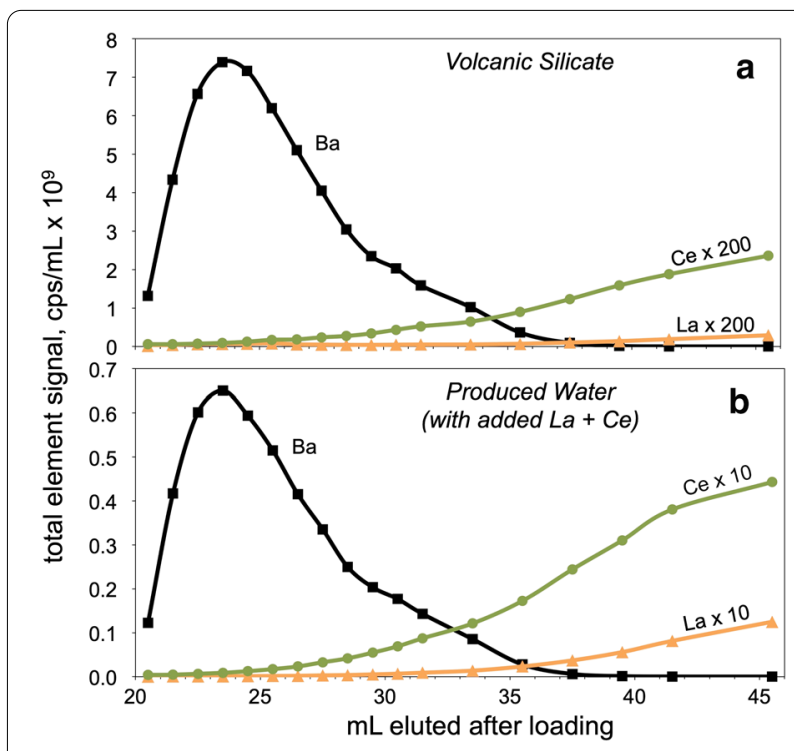

Fig. 3 Separation of Ba from isobaric interferents La and Ce during elution of $2 \mathrm{~N} \mathrm{HNO}_{3}$. The $y$-axis is the signal intensity (in counts per second by SF-ICP-MS) per mL of each column cut, recalculated to reflect the total element signal rather than just the measured isotope. The La and Ce signals are multiplied by the factors shown on the curves; if plotted at their actual intensities, the curves would be barely distinguishable above baseline. The $\mathrm{La} / \mathrm{Ba}$ and $\mathrm{Ce} / \mathrm{Ba}$ of the volcanic silicate sample (a) prior to loading was $\sim 0.014$ and $\sim 0.033$, respectively, while La and Ce were added to the produced water sample (b) prior to loading to generate high $\mathrm{La} / \mathrm{Ba}$ and $\mathrm{Ce} / \mathrm{Ba}$ ratios of $\sim 0.67$ 
which can be done accurately. However, most geologic materials have $\mathrm{Ce} / \mathrm{Ba}$ ratios (Table 2) considerably lower than the artificially Ce-enriched produced water reported here $(\mathrm{Ce} / \mathrm{Ba} \approx 0.25)$. Unusual natural samples with very high $\mathrm{Ce} / \mathrm{Ba}$ could be run through the same column twice to remove any excess $\mathrm{Ce}$.

In the optimal separation procedure, a total of $20 \mathrm{~mL}$ $2.5 \mathrm{~N} \mathrm{HCl}$ is used to elute the major matrix elements. Barium is eluted using $12 \mathrm{~mL}$ of $2.0 \mathrm{~N} \mathrm{HNO}_{3}$ (Fig. 2). Major elements were effectively removed prior to the $\mathrm{Ba}$ cut; the results were similar for all samples tested (silicate, barite, and fluid samples). The REE isobaric interferents ( $\mathrm{La}$ and $\mathrm{Ce}$ ) only begin to elute from the columns after collection of the Ba cut. Additional Ce and La was added to the dissolved aliquot of carbonate (PA-LO102714) prior to loading in the column to verify separation of Ba from these mass interferents (Fig. 2). Because $\mathrm{HNO}_{3}$ so effectively delays release of La and Ce, these elements were not fully removed from the columns even after adding $40 \mathrm{~mL}$ of $2 \mathrm{~N} \mathrm{HNO}_{3}$ (following $20 \mathrm{~mL}$ of $2.5 \mathrm{~N} \mathrm{HCl}$ ). For all samples, including biogenic carbonate, silicate volcanic rock, organic-rich shales, and high TDS oil and gas produced brine, use of the method resulted in the release of major elements (e.g., $\mathrm{Ca}, \mathrm{Na}, \mathrm{K}, \mathrm{Al}$ ) from the sample matrix during the $\mathrm{HCl}$ elution. Barium was eluted during the nitric acid step, and La and Ce were effectively held on the resin until the bulk of the Ba was eluted. Using gravity flow, the total time from sample loading to removal of the Ba cut is 3-4 h. With a 24-sample column holder, processing 48 samples/day is easily achievable by a single user. The rate-limiting step is preparing the samples for column work (dissolution, evaporation, precipitation of $\mathrm{Ba}$ when needed).

The maximum procedural blank for $\mathrm{Ba}$, determined by the limits of detection by SF-ICP-MS, was $2 \mathrm{ng}$ of Ba, leading to a maximum $\delta^{138} \mathrm{Ba}$ uncertainty of $\pm 0.002 \%$ o for a $2 \mu \mathrm{g}$ sample. This assumes the maximum isotopic difference between the sample and blank of $2 \%$, equivalent to the entire range of $\delta^{138} \mathrm{Ba}$ values measured to date [20]. This is well within the in-run uncertainty of $\pm 0.03 \%$ or better for the MC-ICPMS analysis.

\section{Verification from $\mathrm{Ba}$ isotope analysis}

Barium isotope analysis of separated samples further demonstrates effective separation. Two silicate rock standards (BCR-2 basalt and AGV-1 andesite) and an internal produced water standard (M4TFA0518) were analyzed after separations using both our previous method [20] and the new method described here. With the previous method (smaller Teflon columns eluted with $2.0 \mathrm{~N} \mathrm{HCl}$, with silicates put through a second time to remove REE interferents), we obtained good agreement of the measured $\delta^{138} \mathrm{Ba}$ with published standard values for silicates [20]. The results of the current analyses are shown in Table 3. Because the isobaric interferences from ${ }^{136} \mathrm{Ce},{ }^{138} \mathrm{Ce}$, and ${ }^{138} \mathrm{La}$ are monitored continuously during the run using ${ }^{139} \mathrm{La}$ and ${ }^{140} \mathrm{Ce}$, we can calculate the total correction to the $\delta^{138} \mathrm{Ba}$ from these interferents. As shown in Table 3, the maximum correction required for $\mathrm{Ce}$ is $0.002 \%$, which is an order of magnitude smaller than the typical in-run uncertainty. The correction required for $\mathrm{La}$ is three orders of magnitude smaller than the typical in-run uncertainty. The ratio of total La to total Ba transmitted into the MC-ICPMS after column separation was $\sim 3 \times 10^{-4}$ of the pre-column ratio, while the $\mathrm{Ce} / \mathrm{Ba}$ ratio after column separation was $9-14 \times 10^{-4}$ of the pre-column value. Given that the interfering isotopes only make up $0.09 \%$ and $0.49 \%$ of the interferent masses measured at ${ }^{139} \mathrm{La}$ and ${ }^{140} \mathrm{Ce}$, respectively, this amounts to a negligible or reliably correctable signal.

The $\delta^{138} \mathrm{Ba}$ value of USGS standard BCR-2 (Table 3) that was processed using the methods described in this paper agree well with values reported previously by Nan et al. [23, 31], An et al. [46] and Tieman et al. [20]. The AGV-1 $\delta^{138} \mathrm{Ba}$ value obtained here agrees with values

Table $2 \mathrm{La} / \mathrm{Ba}$ and Ce/Ba ranges for various geologic and hydrologic materials

\begin{tabular}{llll}
\hline Material & La/Ba & Ce/Ba & References \\
\hline Upper Continental Crust & 0.056 & 0.12 & {$[47]$} \\
Lower Continental Crust & 0.071 & 0.15 & {$[47]$} \\
Ocean Ridge Basalts & $0.3-53$ & $0.045-10$ & {$[48]$} \\
Peridotite & $0.019-0.48$ & $0.0033-2.0$ & {$[49]$} \\
Shale & $0.023-0.071$ & $0.11-0.15$ & {$[47,50]$} \\
Marine carbonate & $0.00037-0.077$ & $0.00029-0.20$ & {$[51,52]$} \\
Barite & $0.000012-0.00055$ & $0.000006-0.00053$ & {$[53]$} \\
Seawater (average) & 0.00037 & 0.000046 & {$[54]$} \\
River water (global average) & 0.0052 & 0.011 & {$[55]$} \\
\hline
\end{tabular}


Table 3 Interference corrections and $\delta^{138}$ Ba values for selected standards

\begin{tabular}{|c|c|c|c|c|c|c|c|}
\hline \multirow[t]{2}{*}{ Standard } & \multicolumn{2}{|c|}{ Unseparated sample ${ }^{a}$} & \multicolumn{2}{|c|}{ Post-separation $^{b}$} & \multicolumn{2}{|c|}{$\%$ correction from ${ }^{c}$} & \multirow[t]{2}{*}{$\delta^{138} \mathrm{Ba}$} \\
\hline & $L a_{T} / B_{T}$ & $C \mathrm{e}_{\mathrm{T}} / \mathrm{Ba}_{\mathrm{T}}$ & $\mathrm{La}_{\mathrm{T}} / \mathrm{Ba}_{\mathrm{T}}$ & $C \mathrm{e}_{\mathrm{T}} / \mathrm{Ba}_{\mathrm{T}}$ & La & $\mathrm{Ce}$ & \\
\hline \multirow[t]{2}{*}{ BCR-2 } & 0.037 & 0.078 & 0.000013 & 0.00011 & -0.00002 & 0.00211 & $0.080 \pm 0.029$ \\
\hline & & & 0.000013 & 0.00011 & -0.00002 & 0.00209 & $0.071 \pm 0.026$ \\
\hline AGV-1 & 0.032 & 0.056 & 0.000011 & 0.000048 & -0.00001 & 0.00090 & $0.067 \pm 0.030$ \\
\hline \multirow[t]{3}{*}{ M4TFA0518 } & $\mathrm{n} / \mathrm{a}$ & $n / a$ & 0.000018 & 0.000034 & -0.00002 & 0.00064 & $0.948 \pm 0.034$ \\
\hline & & & 0.000018 & 0.000034 & -0.00002 & 0.00064 & $0.936 \pm 0.037$ \\
\hline & & & 0.000018 & 0.000035 & -0.00002 & 0.00066 & $0.902 \pm 0.033$ \\
\hline SRM 3104a & $\mathrm{n} / \mathrm{a}$ & $\mathrm{n} / \mathrm{a}$ & 0.0000053 & 0.0000016 & -0.00001 & 0.00003 & \\
\hline
\end{tabular}

n/a no data available

${ }^{\text {a }}$ Ratio of total La or Ce to Ba in unseparated sample based on values reported by Raczek et al. [37]

${ }^{\mathrm{b}}$ Ratio of total La or Ce to Ba in separated Ba cut based on MC-ICPMS measured intensity of ${ }^{138} \mathrm{Ba},{ }^{139} \mathrm{La}$, and ${ }^{140} \mathrm{Ce}$

${ }^{\mathrm{c}}$ Total correction applied to $\delta^{138} \mathrm{Ba}$ value (per mil) from measured ${ }^{139} \mathrm{La}$ and ${ }^{140} \mathrm{Ce}$ during analysis

d Internal lab standard-Marcellus Shale gas well produced water

reported by Nan et al. [23, 31], van Zuilen et al. [24], An et al. [46] and Tieman et al. [20].

\section{Conclusions}

We describe a method of Ba separation by cation exchange using readily available, disposable columns suitable for varied sample matrices, including silicates, carbonates, seawater, sulfates, brines, and produced waters. Eluting with $2.5 \mathrm{~N} \mathrm{HCl}$ ensures the removal of major elements while $\mathrm{Ba}$ is still in the column, and the subsequent elution with $2.0 \mathrm{~N} \mathrm{HNO}_{3}$ separates Ba effectively from REE mass interferents. We show that matrix and isobaric interferents can be removed from most sample types in a single step, with no need for an additional cleanup column. In addition, the use of disposable columns prevents possible cross contamination when dealing with complex sample matrices. The moderate column size and elution volumes allow for rapid (3-4 h) simultaneous separation of multiple samples.

\section{Supplementary Information}

The online version contains supplementary material available at https://doi. org/10.1186/s12932-021-00077-z.

Additional file 1: Table S1. Information on samples used for column calibration experiments. Table S2. Thermo Element ${ }^{\circledR}$ ICP-MS signal intensity (in counts per second) for a column calibration using $2.0 \mathrm{~N} \mathrm{HCl}$ for the entire elution of a dissolved silicate volcanic rock. Table S3. Thermo Element ${ }^{\circledR}$ ICP-MS signal intensity (in counts per second) for a column calibration using $2.5 \mathrm{~N} \mathrm{HCl}$ for the entire elution of a dissolved silicate volcanic rock. Table S4. Thermo Element ${ }^{\circledR}$ ICP-MS signal intensities (in counts per second) for a column calibration using $2.5 \mathrm{~N} \mathrm{HCl}$ for the first $20 \mathrm{~mL}$, and $3.0 \mathrm{~N} \mathrm{HNO} 3$ for the remaining elution of a produced water sample with $0.5 \mu \mathrm{g}$ of La and Ce added. Table S5. Thermo Element ${ }^{\circledR}$ ICP-MS signal intensities (in counts per second) for a column calibration using $2.5 \mathrm{~N} \mathrm{HCl}$ for the first $20 \mathrm{~mL}$, and $2.0 \mathrm{~N} \mathrm{HNO} 3$ for the remaining elution of dissolved freshwater mussel shell calcium carbonate. Figure S1. Examples of column matrix separation for major elements, $\mathrm{Ba}$, and isobaric interferents
La and Ce for a volcanic silicate sample using the BIO-RAD Poly-Prep ${ }^{\circledR}$ gravity flow ion exchange columns described in the manuscript. Figure S2. Examples of column matrix separation of Ba from isobaric interferents La and Ce for a produced water sample (a) and calcium carbonate sample (b) using the BIO-RAD Poly-Prep ${ }^{\circledR}$ gravity flow ion exchange columns described in the manuscript.

\section{Acknowledgements}

We thank W. Heck for assistance with column calibrations. We appreciate comments from two anonymous reviewers.

\section{Authors' contributions}

RMM carried out the dissolution and Ba separation experiments, wrote the first draft, and edited subsequent drafts; BWS and RCC helped plan the experiments, carried out Ba isotope analyses, assisted with data interpretation, and edited the manuscript; RLT analyzed the column elution concentrations and edited the manuscript; JAH helped plan the experiments and edited the manuscript. All authors read and approved the final manuscript.

\section{Funding}

This work was supported by the U.S. Department of Energy, Office of Fossil Energy Advanced Carbon Storage and Onshore Unconventional portfolios, and by an Oak Ridge Institute for Science and Education research internship to RMM.

This work was funded by the Department of Energy, National Energy Technology Laboratory, an agency of the United States Government, through a support contract with Leidos Research Support Team (LRST). Neither the United States Government nor any agency thereof, nor any of their employees, nor LRST, nor any of their employees, makes any warranty, expressed or implied, or assumes any legal liability or responsibility for the accuracy, completeness, or usefulness of any information, apparatus, product, or process disclosed, or represents that its use would not infringe privately owned rights. Reference herein to any specific commercial product, process, or service by trade name, trademark, manufacturer, or otherwise, does not necessarily constitute or imply its endorsement, recommendation, or favoring by the United States Government or any agency thereof. The views and opinions of authors expressed herein do not necessarily state or reflect those of the United States Government or any agency thereof.

Availability of data and materials

The dataset supporting the conclusions of this article is included within the article or in Additional file 1. 


\section{Declarations}

\section{Competing interests}

The authors declare that they have no competing interests.

\section{Author details}

'Department of Geology \& Environmental Science, University of Pittsburgh, Pittsburgh, PA 15260, USA. ${ }^{2}$ National Energy Technology Laboratory, 626 Cochrans Mill Road, P.O. Box 10940, Pittsburgh, PA 15236-0940, USA. ${ }^{3}$ NETL Support Contractor, 626 Cochrans Mill Road, P.O. Box 10940, Pittsburgh, PA 15236-0940, USA.

Received: 13 May 2021 Accepted: 24 July 2021

Published online: 11 August 2021

\section{References}

1. Church TM, Wolgemuth (1972) Marine barite saturation. Earth Planet Sci Lett 15:35-44

2. Bacon MP, Edmond JM (1972) Barium and GEOSECS III in the southwest Pacific. Earth Planet Sci Lett 16:66-74

3. Chan LH, Edmond JM, Stallard RF, Broecker WS, Chung YC, Weiss RF, Ku TL (1976) Radium and barium at GEOSECS stations in the Atlantic and Pacific. Earth Planet Sci Lett 32:258-267

4. Griffith EM, Paytan A (2012) Barite in the ocean-occurrence, geochemistry and palaeoceanographic applications. Sedimentology 59:1817-1835

5. Carter SC, Paytan A, Griffith EM (2020) Toward an improved understanding of the marine barium cycle and the application of marine barite as a paleoproductivity proxy. Minerals 10:421

6. von Allmen K, Böttcher ME, Samankassou E, Nägler TF (2010) Barium isotope fractionation in the global barium cycle: first evidence from barium minerals and precipitation experiments. Chem Geol 277:70-77

7. Horner TJ, Kinsley CW, Nielsen SG (2015) Barium-isotopic fractionation in seawater mediated by barite cycling and oceanic circulation. Earth Planet Sci Lett 430:511-522

8. Bullen T, Chadwick O (2016) Ca, Sr and Ba stable isotopes reveal the fate of soil nutrients along a tropical climosequence in Hawaii. Chem Geol 422:25-45

9. Cao Z, Siebert C, Hathorne EC, Dai M, Frank M (2016) Constraining the oceanic barium cycle with stable barium isotopes. Earth Planet Sci Lett 434:1-9

10. Bates SL, Hendry KR, Pryer HV, Kinsley CW, Pyle KM, Woodward EMS, Horner TJ (2017) Barium isotopes reveal role of ocean circulation on barium cycling in the Atlantic. Geochim Cosmochim Acta 204:286-299

11. Hsieh Y-T, Henderson GM (2017) Barium stable isotopes in the global ocean: tracer of Ba inputs and utilization. Earth Planet Sci Lett 473:269-278

12. Bridgestock L, Hsieh Y-T, Porcelli D, Homoky WB, Bryan A, Henderson GM (2018) Controls on the barium isotope compositions of marine sediments. Earth Planet Sci Lett 481:101-110

13. Hendry KR, Pyle KM, Butler GB, Cooper A, Fransson A, Chierici M, Leng MJ, Meyer A, Dodd PA (2018) Spatiotemporal variability of barium in Arctic sea-ice and seawater. J Geophys Res Oceans 123:3507-3522

14. Crockford PW, Wing BA, Paytan A, Hodgskiss MSW, Mayfield KK, Hayles JA, Middleton JE, Ahm A-SC, Johnston DT, Caxito F, Uhlein G, Halverson GP, Eickmann B, Torres M, Horner TJ (2019) Barium-isotopic constraints on the origin of post-Marinoan barites. Earth Planet Sci Lett 519:234-244

15. Gou L-F, Jin Z, Galy A, Gong Y-Z, Nan X-Y, Jin C, Wang X-D, Bouchez J, Cai $\mathrm{H}-\mathrm{M}$, Chen J-B, Yu H-M, Huang F (2020) Seasonal riverine barium isotopic variation in the middle Yellow River: Sources and fractionation. Earth Planet Sci Lett 531:115990

16. Gong Y, Zeng Z, Cheng W, Lu Y, Zhang L, Yu H, Huang F (2020) Barium isotopic fractionation during strong weathering of basalt in a tropical climate. Environ Int 143:105896

17. Renock D, Landis JD, Sharma M (2016) Reductive weathering of black shale and release of barium during hydraulic fracturing. Appl Geochem 65:73-86

18. Paukert Vankeuren AN, Hakala JA, Jarvis K, Moore JE (2017) Mineral reactions in shale gas reservoirs: barite scale formation from reusing produced water as hydraulic fracturing fluid. Environ Sci Technol 51:9391-9402

19. Jew AD, Li Q, Cercone D, Maher K, Brown GE, Jr., Bargar JR (2018) Barium sources in hydraulic fracturing systems and chemical controls on its release into solution. Unconventional Resources Technology Conference (URTeC), paper 2899671. https://doi.org/10.15530/urtec-2018-2899671

20. Tieman ZG, Stewart BW, Capo RC, Phan TT, Lopano CL, Hakala JA (2020) Barium isotopes track the source of dissolved solids in produced water from the unconventional Marcellus Shale gas play. Environ Sci Technol 54:4275-4285

21. Andreasen R, Sharma M (2007) Mixing and homogenization in the early solar sytem: clues from $\mathrm{Sr}, \mathrm{Ba}, \mathrm{Nd}$, and $\mathrm{Sm}$ isotopes in meteorites. Astrophys J 665:874-883

22. Barling J, Weis D (2008) Influence of non-spectral matrix effects on the accuracy of $\mathrm{Pb}$ isotope ratio measurement by MC-ICP-MS: implications for the external normalization method of instrumental mass bias correction. J Anal Atom Spectrom 23:1017

23. Nan X, Wu F, Zhang Z, Hou Z, Huang F, Yu H (2015) High-precision barium isotope measurements by MC-ICP-MS. J Anal Atom Spectrom 30:2307-2315

24. van Zuilen K, Nägler TF, Bullen TD (2016) Barium isotopic compositions of geological reference materials. Geostand Geoanalyt Res 40:543-558

25. Zeng Z, Li X, Liu Y, Huang F, Yu HM (2019) High-precision barium isotope measurements of carbonates by MC-ICP-MS. Geostand Geoanalyt Res 43:291-300

26. Lin Y-B, Wei H-Z, Jiang S-Y, Hohl S, Lei H-L, Liu X, Dong G (2020) Accurate determination of barium isotopic compositions in sequentially leached phases from carbonates by double spike-thermal ionization mass spectrometry (DS-TIMS). Anal Chem 92:2417-2424

27. Yu Y, Siebert C, Fietzke J, Goepfert T, Hathorne E, Cao Z, Frank M (2020) The impact of MC-ICP-MS plasma conditions on the accuracy and precision of stable isotope measurements evaluated for barium isotopes. Chem Geol 549:119697

28. Tian L-L, Zeng Z, Nan X-Y, Yu H-M, Huang F (2019) Determining Ba isotopes of barite using the $\mathrm{Na}_{2} \mathrm{CO}_{3}$ exchange reaction and double-spike method by MC-ICP-MS. J Anal Atom Spectrom 34:1459-1467

29. Tian L-L, Gong Y-Z, Wei W, Kang J-T, Yu H-M, Huang F (2020) Rapid determination of $\mathrm{Ba}$ isotope compositions for barites using a $\mathrm{H}_{2} \mathrm{O}$-extraction method and MC-ICP-MS. J Anal Atom Spectrom 35:1566-1573

30. Miyazaki T, Kimura J-I, Chang Q (2014) Analysis of stable isotope ratios of Ba by double-spike standard-sample bracketing using multiple-collector inductively coupled plasma mass spectrometry. J Anal Atom Spectrom 29:483

31. Nan X-Y, Yu H-M, Rudnick RL, Gaschnig RM, Xu J, Li W-Y, Zhang Q, Jin Z-D, Li X-H, Huang F (2018) Barium isotopic composition of the upper continental crust. Geochim Cosmochim Acta 233:33-49

32. Foster DA, Staubwasser M, Henderson GM (2004) ${ }^{226} \mathrm{Ra}$ and Ba concentrations in the Ross Sea measured with multicollector ICP mass spectrometry. Mar Chem 87:59-71

33. Merschel G, Bau M (2015) Rare earth elements in the aragonitic shell of freshwater mussel Corbicula fluminea and the bioavailability of anthropogenic lanthanum, samarium and gadolinium in river water. Sci Total Environ 533:91-101

34. Barbot E, Vidic NS, Gregory KB, Vidic RD (2013) Spatial and temporal correlation of water quality parameters of produced waters from Devonian-age shale following hydraulic fracturing. Environ Sci Technol 47:2562-2569

35. Ouyang B, Akob DM, Dunlap D, Renock D (2017) Microbially mediated barite dissolution in anoxic brines. Appl Geochem 76:51-59

36. Cole RB, Stewart BW (2009) Continental margin volcanism at sites of spreading ridge subduction: examples from southern Alaska and western California. Tectonophysics 464:118-136

37. Raczek I, Stoll B, Hofmann AW, Jochum KP (2001) High-precision trace element data for the USGS reference materials BCR-1, BCR-2, BHVO-1, BHVO-2, AGV-1, AGV-2, DTS-1, DTS-2, GSP-1 and GSP-2 by ID-TIMS and MIC-SSMS. Geostand Newslett 25:77-86

38. Breit GN, Simmons EC, Goldhaber MB (1985) Dissolution of barite for the analysis os strontium isotopes and other chemical and isotopic variations using aqueous sodium carbonate. Chem Geol (Isotope Geosc Sect) 52:333-336 
39. Horner TJ, Pryer HV, Nielsen SG, Crockford PW, Gauglitz JM, Wing BA, Ricketts RD (2017) Pelagic barite precipitation at micromolar ambient sulfate. Nat Commun 8:1342

40. Böttcher ME, Geprägs P, Neubert N, von Allmen K, Pretet C, Samankassou E, Nägler TF (2012) Barium isotope fractionation during experimental formation of the double carbonate BaMn[ $\left[\mathrm{CO}_{3}\right]_{2}$ at ambient temperature. Isotopes Env Health Stud 48:457-463

41. Mavromatis $V$, van Zuilen $K$, Purgstaller B, Baldermann A, Nägler TF, Dietzel $\mathrm{M}$ (2016) Barium isotope fractionation during witherite $\left(\mathrm{BaCO}_{3}\right)$ dissolution, precipitation and at equilibrium. Geochim Cosmochim Acta 190:72-84

42. Pretet C, van Zuilen K, Nägler TF, Reynaud S, Böttcher ME, Samankassou E (2016) Constraints on barium isotope fractionation during aragonite precipitation by corals. Deposit Rec 1:118-129

43. van Zuilen K, Müller T, Nägler TF, Dietzel M, Küsters T (2016) Experimental determination of barium isotope fractionation during diffusion and adsorption processes at low temperatures. Geochim Cosmochim Acta 186:226-241

44. Rudge JF, Reynolds BC, Bourdon B (2009) The double spike toolbox. Chem Geol 265:420-431

45. Wasserburg GJ, Jacobsen SB, DePaolo DJ, McCulloch MT, Wen T (1981) Precise determination of $\mathrm{Sm} / \mathrm{Nd}$ ratios, $\mathrm{Sm}$ and $\mathrm{Nd}$ isotopic abundances in standard solutions. Geochim Cosmochim Acta 45:2311-2323

46. An YJ, Li X, Zhang ZF (2020) Barium isotopic compositions in thirty-four geological reference materials analysed by MC-ICP-MS. Geostand Geoanalyt Res 44:183-199

47. McLennan SM (2001) Relationship between the trace element composition of sedimentary rocks and upper continental crust. Geochem Geophy Geosyst. https://doi.org/10.1029/2000GC000109
48. Gale A, Dalton CA, Langmuir CH, Su Y, Schilling J-G (2013) The mean composition of ocean ridge basalts. Geochem Geophy Geosyst 14:489-518

49. Niu Y (2004) Bulk-rock major and trace element compositions of abyssal peridotites: implications for mantle melting, melt extraction and postmelting processes beneath mid-ocean ridges. J Petrol 45:2423-2458

50. Gromet LP, Dymek RF, Haskin LA, Korotev RL (1984) The "North American shale composite": its compilation, major and trace element characteristics. Geochim Cosmochim Acta 48:2469-2482

51. Li F, Webb GE, Algeo TJ, Kershaw S, Lu C, Oehlert AM, Gong Q, Pourmand A, Tan X (2019) Modern carbonate ooids preserve ambient aqueous REE signatures. Chem Geol 509:163-177

52. Geyman BM, Ptacek JL, LaVigne M, Horner TJ (2019) Barium in deep-sea bamboo corals: Phase associations, barium stable isotopes, \& prospects for paleoceanography. Earth Planet Sci Lett 525:115751

53. Guichard F, Church TM, Treuil M, Jaffrezic H (1979) Rare earths in barites: distribution and effects on aqueous partitioning. Geochim Cosmochim Acta 43:983-997

54. Nozaki Y (1997) A fresh look at element distribution in the North Pacific Ocean. Eos 78:221-223

55. Gaillardet J, Viers J, Dupré B (2005) Trace elements in river waters. In: Drever II (ed) Surface and Ground Water, Weathering, and Soils: Treatise on Geochemistry, vol 5. Elsevier, pp 225-272

\section{Publisher's Note}

Springer Nature remains neutral with regard to jurisdictional claims in published maps and institutional affiliations.
Ready to submit your research? Choose BMC and benefit from:

- fast, convenient online submission

- thorough peer review by experienced researchers in your field

- rapid publication on acceptance

- support for research data, including large and complex data types

- gold Open Access which fosters wider collaboration and increased citations

- maximum visibility for your research: over $100 \mathrm{M}$ website views per year

At $\mathrm{BMC}$, research is always in progress.

Learn more biomedcentral.com/submissions 